\title{
The Relationship between Terminal Bud Death and Programmed Cell Death in Paulownia spp.
}

\author{
Wang Yanmei ${ }^{1}$, Ma Tianxiao ${ }^{1,2}$, Liu Zhen ${ }^{1 *}$ \\ ${ }^{1}$ Forestry Department, Henan Agricultural University, \\ Nongye Road NO.63, Zhengzhou 450002, People's Republic of China \\ ${ }^{2}$ Huanghe University of Science and Technology, \\ Zijingshan Road No.666, Zhengzhou 450000, People's Republic of China
}

Received: 1 July 2017

Accepted: 6 August 2017

\begin{abstract}
To investigate the reasons for terminal bud death, the relationship between terminal bud death and programmed cell death in Paulownia was studied using morphocytology and DNA ladder techniques with one-year-old seedlings of Paulownia spp. The results showed that there were no characteristic morphological changes of the chromatin/chromosomes or nucleus, such as chromatin condensation, nuclear shrinkage, distortion, or degradation after DAPI (4',6-diamidino-2-phenylindo-le) staining, and DNA laddering was not found in cells after agarose gel electrophoresis. Preliminarily results suggest that the terminal bud death of Paulownia spp. is not clearly related to programmed cell death.
\end{abstract}

Keywords: Paulownia spp., terminal bud death, programmed cell death, DAPI, DNA ladder

\section{Introduction}

In China, Paulownia spp. are important cultivated trees used to produce fast-growing timber as well as for intercropping in agricultural regions, greening, and landscaping. Paulownia spp. grow quickly and form beautiful trees with very attractive shapes and flowers. The wood does not warp or crack easily, is widely used in furniture production and agricultural construction, and is popular among many people. It is also an important export to foreign markets (such as Japan, Australia, and other countries). Developing the various Paulownia spp. has

*e-mail: liuzh20@163.com important ecological, economic, and social significance, such as improving environmental conditions, resolving wood shortages, and improving the standard of living for farmers. In production, 'big crowns and low trunks' not only directly affect the yield and quality of Paulownia spp. wood, but also intercropped crops. The cause of "big crowns and low trunks" is the death of terminal buds. According to prior studies, terminal bud death can arise from low temperature, water, or cold-water stress, or physiological and ecological adaptations in the process of long-term evolution [1]. However, the reasons for terminal bud death are disputed.

Programmed cell death (PCD) is a genetically determined process that occurs at all stages of the life cycle in plants, including growth, development, and the death of the whole plant [2]. It also plays an important 
role in plants exposed to a broad range of biotic and abiotic stress stimuli such as pathogen-plant interactions (known as the hypersensitive response), low temperatures [3], high temperatures [4], waterlogging [5], and heavy metal pollution [6]

To investigate the relationship between terminal bud death and PCD in Paulownia spp., we performed empirical studies on bud cell morphological characteristics and DNA fragmentation. These results may provide a useful theoretical and technical basis for regulating the growth of Paulownia spp.

\section{Materials and Methods}

\section{Experimental Plot}

The experimental plot was located in the Forestry Experiment Station of the Third Living Area, Henan Agricultural University, Zhengzhou City, China $\left(113^{\circ} 38^{\prime} \mathrm{E}, 34^{\circ} 48^{\prime} \mathrm{N}\right)$. The warm temperate continental climate has four distinct seasons with annual average, maximum, and minimum temperatures of $14.2^{\circ} \mathrm{C}, 43^{\circ} \mathrm{C}$, and $-17.9^{\circ} \mathrm{C}$, respectively. The accumulated temperature $\geq 10^{\circ} \mathrm{C}$ is $4,717^{\circ} \mathrm{C}$ with a frost-free period of 215 $\mathrm{d}$. The average annual precipitation is $650.1 \mathrm{~mm}$ and the annual duration of sunshine is about $2,400 \mathrm{~h}$. The sandy loam soil of the experimental plot has a $\mathrm{pH}$ of about 7.0.

\section{Experimental Material}

Paulownia tomentosa (Thunb.) Steud. were one-yearold container seedlings. The seedlings had an average height of $49.37 \mathrm{~cm}$ and an average diameter of $1.38 \mathrm{~cm}$.

\section{Experimental Design}

To observe the seedling bud nuclear morphological characteristics by the DAPI method, sampling was conducted from 1 August to 15 November. The interval was one week, and 15 buds were taken each time. To analyze the dynamic changes in terminal bud DNA laddering, sampling was conducted from 1 August to 15 November. The sampling interval was one week, and two samples were taken each time (one of the samples was a spare). Each sample was $1 \mathrm{~g}$. The samples were placed in a $-20^{\circ} \mathrm{C}$ freezer after liquid nitrogen treatment.

\section{Test Methods}

DAPI staining was performed according to [7]. Terminal bud DNA was extracted by the CTAB method [8]. DNA laddering was analyzed following the method of Ulukaya [9].

\section{Results}

\section{Analysis of Cell Nuclear Morphological Changes in Paulownia spp. with DAPI}

DAPI (4',6-diamidino-2-phenylindole) is a kind of nuclear fluorescent dye that can bind with DNA. Fig. 1 shows that Paulownia spp. nuclei at different time points were completely circular, showed bright fluorescence, and did not show apoptotic changes. From August 1 to November 15, the cell nuclei of Paulownia spp. terminal buds remained fully circular. The nuclei did not show typical PCD symptoms such as cytoplasmic or chromatin condensation, chromatin pyknosis and marginalization, nuclear disintegration, or the formation of apoptotic bodies.

\section{DNA Electrophoresis of Paulownia spp. at Different Time Points}

Endogenous endonucleases are activated during the process of cell apoptosis. The resultant DNA laddering is an important biochemical parameter of PCD. Cuts in the nuclear material can be visualized by DNA agarose gel electrophoresis. Here, the DNA of Paulownia spp. terminal buds cells showed a single major band. A DNA ladder uniformly spaced at 180-200 bp did not appear over time (Fig. 2), i.e., there was no clear DNA "ladder," so there were no typical PCD biochemical characteristics.

\section{Discussion and Conclusion}

PCD can be defined as organized cellular destruction and can be activated throughout plant development, as a defense response against invading pathogens or during environmental stress. PCD is an active pattern of cell death controlled by genes; characteristic features include cell shrinkage, chromatin condensation, DNA strand breaks, and DNA fragmentation [10]. The response of most plants exposed to toxic environmental factors is usually connected with cell death and organ necrosis. It is frequently difficult to determine whether the observed death is of destructive character, manifested in an uncontrolled spread, or is the effect of programmed and controlled cell self-destruction, which is generally known as PCD.

Several methods are currently used to measure PCD in plants [11]. These can be divided into microscopic and biochemical methods. Biochemical methods for the detection of PCD in plants include the isolation of DNA from tissues and the detection of DNA fragmentation via a conventional DNA ladder. Microscopy is the most direct way to identify PCD. Staining with fluorescent dyes such as DAPI, PI (propidiumiodide), EB (ethidium 


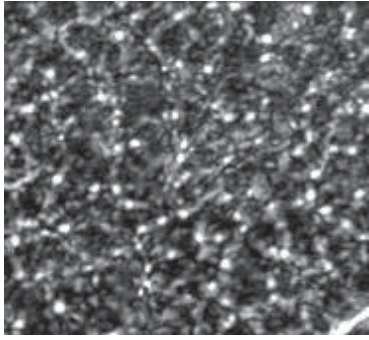

1 August

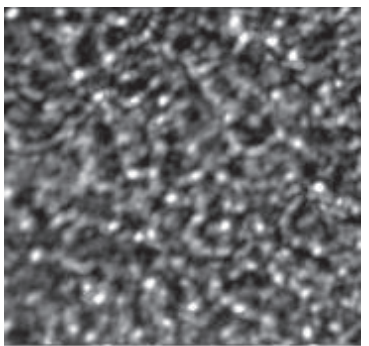

22 August

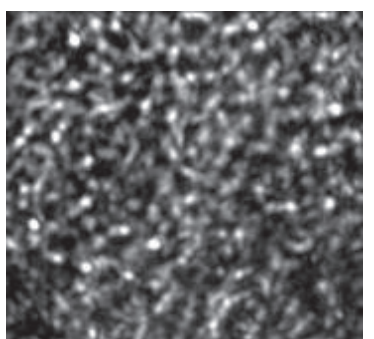

12 September

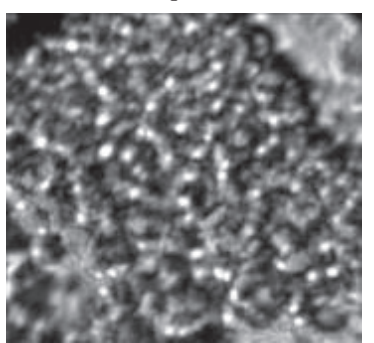

3 October

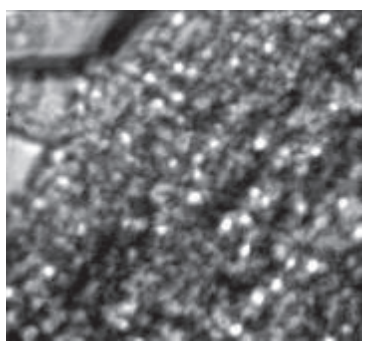

24 October

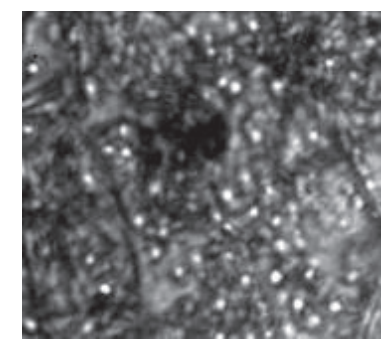

15 November 2010

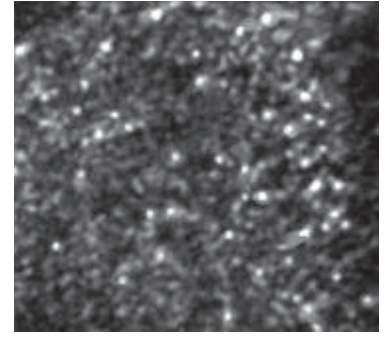

8 August

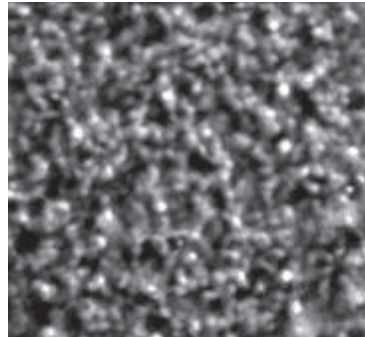

29 August

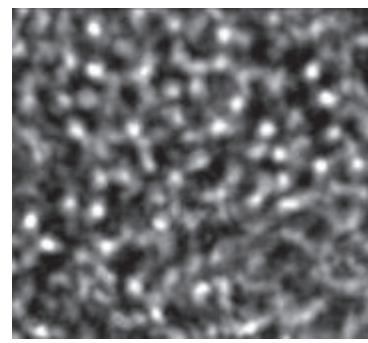

19 September

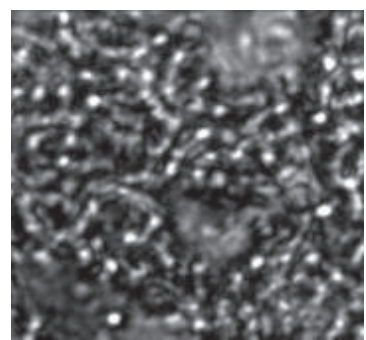

10 October

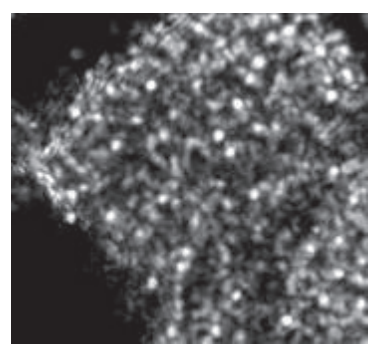

31 October

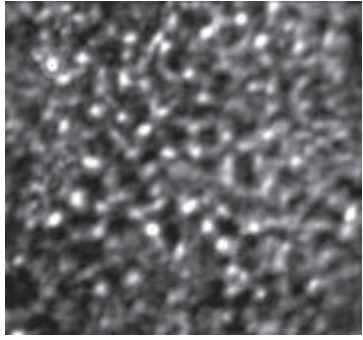

15 August

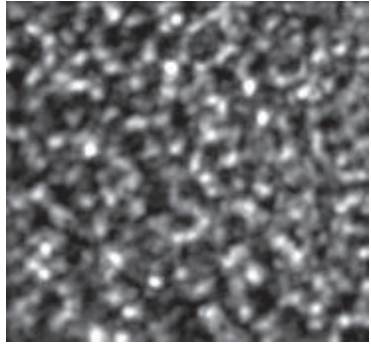

5 September

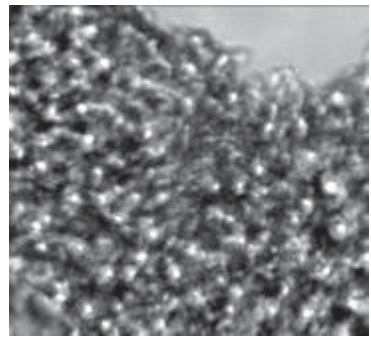

26 September

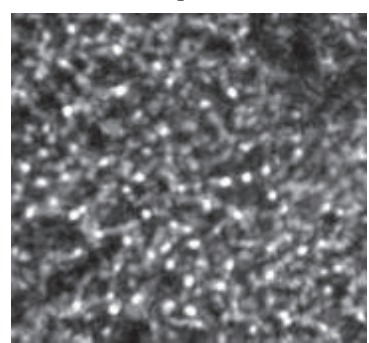

17 October

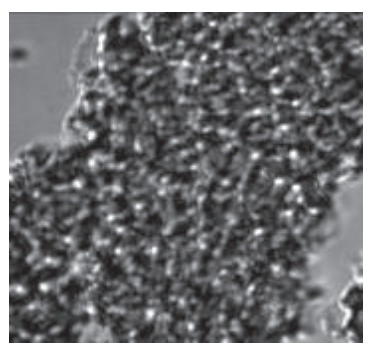

8 November

Fig. 1. Terminal bud nuclear morphological features of Paulownia spp. observed by fluorescence microscopy (from 1 August to 15 November). 


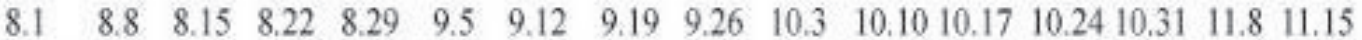

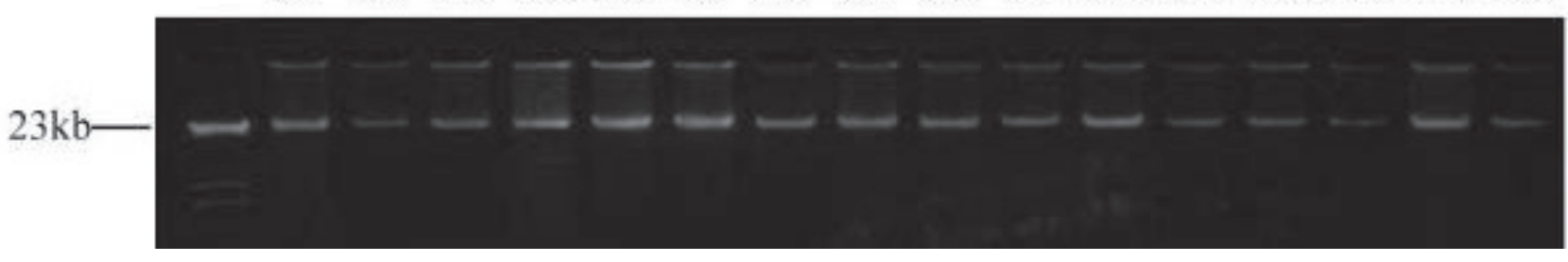

Fig. 2. DNA of Paulownia spp. terminal bud cells after agarose gel electrophoresis.

bromide), AO (acridine orange), and others can be used to observe changes in the nucleus, vacuole formation, and the formation of apoptotic bodies. DAPI as a specific fluorescent probe has been widely used in various fields of cellular and molecular biology to detect PCD. DAPI can quickly combine with nuclei and emits a strong blue fluorescence. A normal nucleus is completely circular and emits uniform bright blue fluorescence. In PCD, the nuclear chromatin is condensed, the nuclei undergo pyknosis and chromatin marginalization and gradually disintegrate, and apoptotic bodies appear and finally disaggregate.

During the process of PCD, DNA laddering can be observed by agarose gel electrophoresis [12]. DNA laddering has become the most important biochemical indicator for the detection of apoptosis. DNA fragmentation is considered to be the "hallmark" of PCD [13]. DNA laddering is the most obvious indicator of PCD in tulip petals [14]. This presents as a 180-200 bp multiplicative DNA ladder in gel electrophoresis.

Eucommia ulmoides Oliv. is a Typical sympodial growing tree. Every year, the normal terminal bud dies. In the following year, it is replaced by a lateral bud. Research has indicated that most apical meristem cells of E. ulmoides bud undergo PCD during the aging process [15]. PCD is a genetically determined process that occurs at all stages of the plant life cycle, starting with seed development and germination [16] and ending with senescence [17].

PCD events are also involved in plant-biotrophic and plant-necrotrophic [18] pathogen interactions, plantplant allelopathic interactions [19], hypoxia [20], heat shock [21], and a variety of stresses such as ozone [22], ultraviolet light [23], salinity [24], low temperature [3], high temperature [4], and heavy metal stress [25].

It had been reported that aluminum (Al) stress altered nitric oxide (NO) concentration and induced programmed cell death (PCD) in plants. Under a fluorescence microscope, DAPI staining can show the change of the nucleus. The nucleus of a normal cell is usually spherical and is located in the middle of the cell without Al stress. Nuclei exposed to Al were flattened, lobed, invaginated, or irregular in shape. Compared with the control, the nuclear became irregular, the normal round nucleus was very little, and chromatin condensation presented a crescent-shaped bend after $100 \mu \mathrm{mol} \mathrm{L} \mathrm{L}^{-1} \mathrm{AlCl}_{3}$ treatment for $4 \mathrm{~h}$. The nucleus damage became more serious with the extension of Al treatment time [26]. Wheat (Triticum aestivum L.) roots were treated with hypoxic water. The staining of cell preparations with DAPI revealed morphological changes of the cells such as nuclear condensation, deformation, and fragmentation [27]. Programmed cell death of Ulmus pumila L. seeds during aging was analyzed. The results showed that the nuclear chromatin appeared to be condensing and shrinking with increasing aging time. Some nuclei dissociated into pieces and were released from the cells. The apoptosis was first observed in the epidermal cells and later in the cotyledons and hypocotyls [28]. The results obtained under transmission electron microscopy (TEM) further revealed apoptotic-like features at the ultrastructural level of PCD-type cells: extensive vacuolization, abnormal chromatin condensation, its marginalization and concomitant degradation, formation of autophagylike vesicles, protoplast shrinkage, fragmentation of cell nuclei, and extensive degeneration of the cells [29]. Wang found that heat stress induced PCD in maize seedling leaves, which was characterized by chromatin DNA laddering and DNA strand breaks detected by a terminal deoxynucleotidyl transferase-mediated dUTP nick end labeling (TUNEL) test [30].

From 1 August to 15 November, the Paulownia spp. nuclei were completely circular, showed bright fluorescence, and did not show a DNA ladder uniformly spaced at 180-200 bp. Thus, there were no typical PCD characteristics.

These preliminary results suggest that the death of Paulownia spp. terminal buds is not caused by PCD.

\section{Acknowledgements}

The authors would like to express their sincere thanks to the personnel of Henan Agricultural University for their kind assistance in the experiments. This research was supported by the Foundation and Leading Edge Research Projects of the Science and Technology Department of Henan Province: "Study on the relationship between the death of Paulownia spp. terminal bud and programmed cell death" (112300410087), and the Natural Science Research Project of the Education Department of Henan Province: "The death mechanism of the terminal bud in Paulownia" (2010A220001). 


\section{References}

1. WANG Y.M, MA TIAN X., LIU Z. Progress in the Death Mechanism Research of Paulownia spp. Terminal Buds. Scientia Silvae Sinicae, 49 (4), 117, 2013.

2. VAN D. W., WOLTERING E.J. Many ways to exit? Cell death categories in plants. Trends in Plant Science, 10 (3), 117, 2005.

3. PAN Y.J., LIU L., LIN Y.C. Ethylene antagonizes saltinduced growth retardation and cell death process via transcriptional controlling of ethylene-, BAG- and senescence-associated genes in Arabidopsis. Frontiers in Plant Science, 7 (175), 696, 2016.

4. DOULE S.M., DIAMON M., MCCABE P.F. Chloroplast and reactive oxygen species involvement in apoptotic-like programmed cell death in Arabidopsis suspension cultures. Journal of Experimental Botany 61 (2), 473, 2010.

5. YU M., ZHOU Z., DENG X. Physiological mechanism of programmed cell death aggravation and acceleration in wheat endosperm cells caused by waterlogging, Acta Physiologiae Plantarum, 39 (1), 23, 2017.

6. ZHAN J., HE H.Y., WANG T.J. Aluminum-induced programmed cell death promoted by AhSAG, a senescenceassociated gene in Arachis hypoganea L. Plant Science, 210C (9), 108, 2013.

7. RYBACZEK D., MUSIALEK M.W., A BALCERCZYK. Caffeine-induced premature chromosome condensation results in the apoptosis-like programmed cell death in root meristems of Vicia faba. PLoS One, 10 (11), e0142307, 2015.

8. TADA Y., HATA S., TAKATA Y., NAKAYASHIKI H., TOSA Y., MAYAMA S. Induction and signaling of an apoptotic response typified by DNA laddering in the defense response of oats to infection and elicitors. Molecular plantmicrobe interactions, 14 (4), 477, 2001.

9. ULUKAYA E., ACILAN C., ARIF. A glance at the methods for detection of apoptosis qualitatively and quantitatively. Turkish Journal of Biochemistry, 36 (3), 261, 2011.

10. XU L.X., CHEN R.J., XU H.J. Identifying stress-related programmed cell death improves research on plant resistance. Chin Sci Bull, 61, 809, 2016.

11. DENG Y.Q.,LIP.,ZHOUY.Progress on detection technology of programmed cell death in plant. Biotechnology Bulletin, 33 (3), 52, 2017.

12. MOCHIZUKI H., SHIBUY K., ICHIMURA K. Programmed cell death begins earlier in the mesophyll cells of tulip petals than in the epidermal cells. Postharvest Biology and Technology, 79 (3), 9, 2013.

13. WYLLIE A.H. The genetic regulation of apoptosis. Current Opinion in Genetics \& Development , 5, 97, 1995.

14. MOCHIZUKI H., SHIBUY K., ICHIMURA K. Programmed cell death begins earlier in the mesophyll cells of tulip petals than in the epidermal cells. Postharvest Biology and Technology, 79 (3), 9, 2013.

15. XU W.J. Study on Molecular markers related to sex of the Eucommia ulmoides Oliv and bud senescence. Peking University, 2003.

16. LOMBARDI L., LORENZI R. Programmed cell death of the nucellus during Sechium edule Sw. seed development is associated with activation of caspase-like proteases. Journal of Experimental Botany, 58(11), 2949, 2007.
17. GUNAWARDENA A., GREENWOOD J.S., DENGLER N.G. Programmed cell death remodels lace plant leaf shape during development.Plant Cell, 16 (1), 60, 2004.

18. FLORVSZAK W.J., ARASIMOWICZ M., MILCZAREK G., JELEN H., JACKOWIAK H. Only an early nitric oxide burst and the following wave of secondary nitric oxide generation enhanced effective defence responses of pelargonium to a necrotrophic pathogen. New Phytologist, 175 (4), 718, 2007.

19. BAIS H.P., RAMARAO V., SIMON G., CALLAWAY R.M., VIVANCO J.M. Allelopathy and exotic plant invasion: from molecules and genes to species interactions. Science, 301 (5638), 1377, 2003.

20. PANG N., ZHANG F. Hypoxia-Induced Programmed Cell Death in Root-Tip Meristematic Cells of Triticum aestivum L. Acta Biologica Cracoviensia S Botanica, 57 (1), $51,2015$.

21. NIAN L.I., ZENG J., YA X.U. Effects of Heat Shock Factor AtHsfAla on Programmed Cell Death in Arabidopsis thaliana under Cold Stress. Agricultural Biotechnology, 3, 57, 2016.

22. KADONO T., TRAN D., ERRAKHI R. Increased anion channel activity is an unavoidable event in ozone-induced programmed cell death. Plos One, 5 (10), e13373, 2010.

23. KRASYLENKO Y., YEMETS A., BLUME Y. Plant microtubules reorganization under the indirect UV-B exposure and during UV-B-induced programmed cell death. Plant Signaling \& Behavior, 8 (5): e24031, 2013.

24. SWAPNIL P., YADAV A.K., SRIVASTAV S. Biphasic ROS accumulation and programmed cell death in a cyanobacterium exposed to salinity $\left(\mathrm{NaCl}\right.$ and $\left.\mathrm{Na}_{2} \mathrm{SO}_{4}\right)$. Algal Research-Biomass Biofuels and Bioproducts, 23, 88, 2017.

25. ARASIMOWICZ J.M., FLORYZSAK W.J., DECKERT J., RUCIŃSKA S.R., GZYL J., PAWLK S.S., ABRAMOWSKI D., JELONEK T., GWÓŹDŹ E. Nitric oxide implication in cadmium-induced programmed cell death in roots and signaling response of yellow lupine plants. Plant Physiology and Biochemistry, 58 (3), 124, 2000.

26. HE H., HUANG W., OO T.L., GU M., HE L.F. Nitric oxide inhibits aluminum-induced programmed cell death in peanut (Arachis hypoganea L.) root tips. Journal of Hazardous Materials, 333, 285, 2017.

27. PANG N., ZHANG F. Hypoxia-Induced programmed cell death in root-tip meristematic cells of Triticum aestivum L. Acta Biologica Cracoviensia Series Botanica, 57(1), 51, 2015.

28. WANG Q., WANG X.F. Programmed cell death of Ulmus pumila L. Seeds during aging and ROS-caspse-3-like pathway mechanism. Acta Botanica Boreali-Occidentalia Sinica, 32 (5), 948, 2012.

29. RYBACZEK D., MUSIALEK M.W., BALCERCZYK A. Caffeine-induced premature chromosome condensation results in the apoptosis-like programmed cell death in root meristems of Vicia faba. Plos One, 10 (11), e0142307, 2015.

30. WANG P., ZHAO L., HOU H.,ZHANG H., HUANG Y.,WANG Y., LI H., GAO F., YAN S., LI L. Epigenetic changes are associated with programmed cell death induced by heat stress in seedling leaves of Zea mays. Plant \& Cell Physiology, 56 (5), 965-976. 2015. 